Article

\title{
An Empirical Investigation of the Longitudinal Effect of Online Consumer Reviews on Hotel Accommodation Performance
}

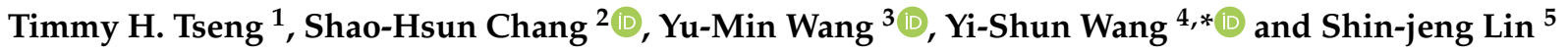 \\ 1 Department of Business Administration, Fu Jen Catholic University, New Taipei City 242062, Taiwan; \\ timmyhtseng@gmail.com \\ 2 Department of Industrial Education and Technology, National Changhua University of Education, \\ Changhua 500, Taiwan; chess1@cc.ncue.edu.tw \\ 3 Department of Information Management, National Chi Nan University, Nantou 54561, Taiwan; \\ ymwang@ncnu.edu.tw \\ 4 Department of Information Management, National Changhua University of Education, \\ Changhua 500, Taiwan \\ 5 Department of Business Administration, Le Moyne College, Syracuse, NY 13214, USA; linsj@lemoyne.edu \\ * Correspondence: yswang@cc.ncue.edu.tw
}

check for updates

Citation: Tseng, T.H.; Chang, S.-H.; Wang, Y.-M.; Wang, Y.-S.; Lin, S.-j. An Empirical Investigation of the Longitudinal Effect of Online Consumer Reviews on Hotel Accommodation Performance. Sustainability 2021, 13, 193. https:// dx.doi.org/10.3390/su13010193

Received: 27 November 2020 Accepted: 23 December 2020 Published: 28 December 2020

Publisher's Note: MDPI stays neutral with regard to jurisdictional claims in published maps and institutional affiliations.

Copyright: (c) 2020 by the authors. Licensee MDPI, Basel, Switzerland. This article is an open access article distributed under the terms and conditions of the Creative Commons Attribution (CC BY) license (https: / / creativecommons.org/ licenses/by/4.0/).

\begin{abstract}
This study empirically investigates the effects of online consumer reviews on hotel accommodation performance in an e-commerce context. Online consumer reviews include two types: online consumer satisfaction and electronic word-of-mouth (eWOM). eWOM was also regarded as the proxy of consumer loyalty. Hotel-level online consumer reviews from three well-known online travel agencies (i.e., Agoda.com, Expedia.com, and Trip.com) and financial data from 88 hotels were combined and analyzed using the Hayes' PROCESS Macro. Based on the service-profit chain (SPC) framework, the two forms of online consumer reviews, satisfaction, and $e W O M$, were hypothesized to have positive effects on performance. The hypothetic effects were assessed in terms of the concurrent model and three lagged models. The results indicate that satisfaction has a positive effect on eWOM. However, to our great surprise, the two forms of online consumer reviews did not directly affect hotel accommodation performance across the concurrent model and the three lagged models. Additionally, online consumer satisfaction did not influence hotel accommodation performance via $e W O M$. The results have several important theoretical and practical implications for online consumer relationship management in the hospitality and tourism industry. The results of this study can further clarify the relationships among online consumer satisfaction and eWOM (customer loyalty), and performance.
\end{abstract}

Keywords: service-profit chain (SPC); online consumer satisfaction; eWOM; hotel accommodation performance; concurrent effect; lagged effect

\section{Introduction}

Firms work to understand how to earn the continued patronage of their consumers in order to compete successfully and operate sustainably [1]. Researchers and professionals alike have identified consumer satisfaction as a key driver of consumer loyalty in both online and offline contexts [2-8]. Consumer satisfaction occurs when a product/service meets the consumer's needs and expectations. A satisfied consumer is more likely to repurchase the product/service in similar, future shopping situations [9]. The repurchase intention or behavior is regarded as consumer loyalty, which correlates positively with firm performance [10-12].

Consumer loyalty refers to a consumer's loyal attitude and behavior toward a specific service firm [13]. Prior studies often use the repurchase intention or behavior of consumers. Kim and Park [14] measured consumer loyalty by consumers' behavioral intention. The measures include consumers' willingness to recommend and intentions to revisit places. Chen [13] also used consumers' behavioral intention to measure consumer loyalty. He used 
four measurement items: revisit intention, frequency of patronage, consumption expenditure, and recommendation intention. With the popularization of Internet applications and the growth of online shopping, many scholars have suggested using eWOM as a measure of customer loyalty [15].

Many researchers have examined the interrelationships among consumer satisfaction, consumer loyalty, and firm performance using the service-profit chain framework [16-18], which postulates that service quality facilitates consumer satisfaction and loyalty, which in turn facilitate firm performance [10,19].

Firm performance is often measured using financial indicators such as return on equity (ROE), return on assets (ROA), and firm stock price. However, both consumer behavior and management ability affect these indicators [20]. Bernhardt et al. [21] found that no significant relationship between customer satisfaction and performance existed, but a positively significant relationship existed between changes in customer satisfaction and changes in the performance of the firm. This may explain why prior studies have found that the relationship between satisfaction and performance is difficult to predict [21]. For example, some studies have found that consumer satisfaction positively influences firm financial performance $[9,22]$, while other studies have found opposite or insignificant effects $[23,24]$. Wiley pointed out that increasing customer satisfaction requires costs, so too high customer satisfaction may lead to negative impacts on performance [24]. Schneider also indicated that it happened under certain conditions that customer satisfaction has a positive effect on performance [23].

These conflicting results indicate the effects of consumer loyalty on firm performance might not be adequately captured by financial metrics. Better measures are needed.

Consumer satisfaction and loyalty are vital for hotels. Although the linkage between consumer satisfaction and loyalty is well-established [25-28], the precise impact on hotel performance remains uncertain. Some studies have identified consumer satisfaction as a prominent driver of hotel performance [12,29], while others have found that this relationship is unclear (e.g., [21,30]). Clearly, more research is necessary to examine the relationships among consumer satisfaction, consumer loyalty, and business performance in the hotel industry.

Many hotels use online travel agency (OTA) websites (e.g., Agoda.com, Booking.com, Expedia.com, and Hotels.com) to reach consumers, and many OTA websites encourage consumers to rate hotels on metrics such as satisfaction with stay and strength of recommendation to other travelers. Therefore, it is imperative for hoteliers to determine the relationship between consumer online responses (i.e., ratings of satisfaction and recommendation) that are posted to OTA websites and a hotel's business performance. Electronic word-of-mouth (eWOM) refers to consumers' sharing of online recommendations and evaluations of products and services [31]. Recommendations passed as eWOM are a form of loyalty [7,32], that have gained importance in the hospitality industry [33]. For consumers, eWOM can be an anonymous, altruistic method of sharing consumption experiences, and it is long-lasting and rapidly disseminated. Some researchers have claimed that $e$ WOM might facilitate hotel performance [34,35]. Based on the service-profit-chain (SPC) framework, the current study examined the relationships among satisfaction, eWOM, and hotel room revenues. These relationships are causal, so both concurrent and lagged effects of online ratings of satisfaction and recommendations on hotel performance were investigated.

This study has three significant features:

First, it focuses on the relationship between online consumer responses and actual hotel performance. Consumers increasingly make their own travel accommodation decisions, make reservations, and pay via hotel websites or on the many OTA websites [36]. The highly autonomous search and purchase behaviors of today's consumers have strengthened their influence on the hotel industry [37].

Second, this study collects online consumer responses from three OTA websites. Prior studies typically adopted self-reported surveys that asked participants to comment on previous experiences, which may have occurred long ago [38,39]. Recollection-based 
data are prone to inaccuracies and biases resulting from the passage of time [40]. The current study aggregated consumers' comments from very recent or currently ongoing stay experiences, which may improve the temporal validity of the measurement.

Finally, the analysis was performed at the hotel level, with a focus on accommodation. By connecting aggregated consumer responses with room revenues at different time points for specific hotels, this study was able to investigate the sequential relationships between satisfaction and $e W O M$ and between $e W O M$ and hotel performance, respectively.

\section{Theoretical Background}

\subsection{Service-Profit Chain (SPC)}

The SPC framework (Figure 1) integrates service delivery with consumer responses and firm performance $[10,18,19]$. It assumes a reciprocal relationship between firms and consumers [41]. Firms that provide excellent service are more likely to satisfy consumer needs, resulting in high levels of consumer loyalty. Loyal consumers tend to patronize the service provider more frequently and spend more. In addition, they serve as a communication medium to disseminate the advantages of that firm's services [42]. Thus, these two loyalty behaviors should contribute positively to firm performance, as measured by revenue and profitability. In sum, the SPC framework explains firm performance through a synthesis of operational activities and consumer responses.

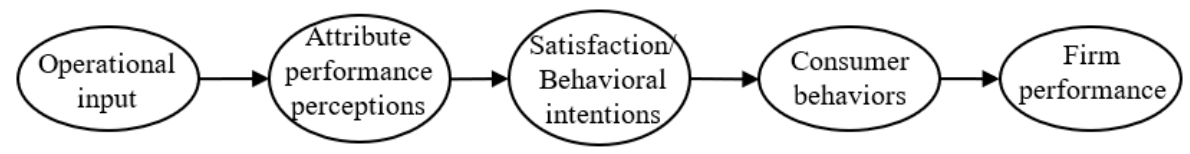

Figure 1. SPC framework, adapted from Kamakura et al. (2002).

\subsection{Online Consumer Reviews}

As the Internet and electronic commerce continue to grow, more and more consumers share their purchase experiences and reviews on the Internet. The behavior is called online consumer reviews. Online consumer reviews refer to consumers' evaluation of purchase satisfaction or $e W O M$ of purchase results [43]. According to prior empirical studies, many online consumers trust online consumer reviews and serve as an important reference for shopping decisions $[44,45]$. Therefore, many studies believe that online consumer reviews have a positive effect on firm performance (sales) and consumer loyalty $[15,46]$.

\subsection{Consumer Satisfaction and Loyalty}

In the field of marketing, satisfaction is viewed as a general post-consumption attitude [22]. Drawing on the disconfirmation paradigm, satisfaction was initially defined as the cognitive evaluation of product performance [5]. By comparing expected to experienced performance, consumers evaluate whether a product satisfies their needs. A high degree of satisfaction is generated when an experienced performance exceeds expected performance. However, an increasing number of researchers have since argued that consumer evaluations of satisfaction also involve emotional reactions (e.g., pleasure/displeasure) that occur during consumption/usage [47]. Han et al. [48] further clarified that the primary source of affective evaluations of satisfaction is cognitive attribute performance. Thus, satisfaction is an attitude that guides consumers' loyalty intentions and future behaviors [49,50].

Repurchase behavior and positive word of mouth (WOM) are two major types of loyalty at both the intention and behavioral levels [26,50-52]. Oliver [6] identified the commitment to repurchase as a form of loyalty intention. Moreover, repurchase frequency and monetary value are common manifestations of behavioral loyalty [53,54]. Loyalty intentions may take the form of consumer commitment to positive WOM. Loyal consumers often freely share their firsthand experiences with other consumers and promote the firms to which they feel loyalty. This behavior can persuade others to purchase from the firm [55]. Consumers who spread positive WOM may provide significant benefits to the firm; therefore, firms view positive WOM as one manifestation of consumer citizenship 
behavior [56]. In sum, consumers require financial, temporal, physical, and psychological resources to develop repurchasing behaviors and spread positive WOM, which are two important manifestations of consumer loyalty.

\subsection{Electronic Word of Mouth (eWOM)}

Hennig-Thurau et al. [57] defined $e W O M$ as "any positive or negative statement made by potential, actual, or former consumers about a product or company, which is made available to a multitude of people and institutions via the Internet." Interpretations of $e W O M$ 's progenitor WOM have focused mostly on oral contexts, such as peer group social interactions [58]. The unique environment for online social interactions provided by the Internet has led to the online, largely text-based, manifestations of WOM being labeled eWOM [59]. Primary channels of eWOM dissemination are online platforms and applications including email, blogs, instant messaging services, and newsgroups. The penetration and reach of the Internet and digital media make $e W O M$ significantly more influential than traditional WOM $[46,60,61]$. The vast number of product reviews and ratings stored online gives them a long-lasting influence on information-seekers. The open nature of $e W O M$ means information is easily accessible to everyone, including people with loose interpersonal connections (weak ties). Koo [31] found that the persuasive effects of $e W O M$ are similar for people with weak and strong ties. In sum, eWOM is an important indicator of consumer loyalty in online contexts.

\section{Hypothesis Development}

\subsection{The Relationship between Satisfaction and Loyalty (eWOM) and Hotel Performance}

In the SPC framework, satisfaction precedes consumer loyalty (i.e., intention to repatronize). As eWOM is a strong measure of consumer loyalty in the hotel industry [34,35], a related inference is that satisfaction facilitates $e W O M$. Past studies have found that satisfaction relates positively to $e W O M$ in various contexts, including restaurants in Iran [62], social media brand communities [8], and mobile phone service promotions [63]. Studies of $e W O M$ and satisfaction in the hotel industry have found that satisfied consumers with few or no complaints do not spread negative WOM [26]. Crotts et al. [64] verified that consumers who are satisfied with a particular hotel-service experience became advocates for that hotel. Similarly, a review of hotel studies by Cantallops and Salvi [34] identified satisfaction as a contributing factor of $e W O M$. Drawing on these previous findings, the current study's first hypothesis is formulated as follows:

Hypothesis 1. Satisfaction relates positively to eWOM.

A number of researchers have argued that satisfaction directly enhances firm performance [21]. Three main arguments have been presented to support this position. First, satisfied consumers are less price-sensitive and are therefore more likely to pay premium prices [47]. Second, these consumers appreciate the services as provided and rarely require after-sales support, helping the firm control operational costs and improve business performance $[65,66]$. Third, interactions with satisfied consumers result in higher repurchase rates, lower consumer-maintenance costs, and lower overall transaction costs [67].

Some studies have elucidated the relationship between consumer response and hotel performance. One analysis by Kim et al. [29] of 95 hotels in the United States found a significant and positive correlation between satisfaction and hotel performance. Sun and Kim [68] collected 13 years of American Customer Satisfaction Index (ACSI) data for nine restaurants, six hotels, and six airlines and found evidence that ACSI rating positively influenced the profitability (i.e., profit margin, ROA, and ROE) and value of these businesses. Based on an analysis of data on 50 three- and four-star hotels, Chi and Gursoy [16] inferred that guest satisfaction is an antecedent of financial success, as measured by managers' subjective evaluations relative to their three major competitors. Phillips et al. [69] linked 68 online platforms and 442 Swiss hotels and found that positive 
consumer evaluations of hotel attributes significantly and positively affected booking numbers and hotel revenues. The second hypothesis of this study builds on this earlier evidence:

Hypothesis 2. Satisfaction relates positively to hotel performance.

\subsection{The Relationship between eWOM and Hotel Performance}

Since $e W O M$ is a key consumer-response variable that reflects consumer loyalty in the hotel industry [34,35], eWOM is expected to have a role in facilitating hotel performance. Aaker [70] showed that intent to share a positive experience (i.e., word-of-mouth) may contribute to firm revenue by influencing other potential consumers. Other studies have also confirmed the positive relationship between WOM and firm performance [35,71,72]. For instance, WOM increases consumer awareness of a product/company, allowing advertising expenses to be reduced, which improves firm performance [32,73]. The persuasive effect of $e W O M$ may reduce the risk perceptions of consumers and lead to improved product acceptance, firm reputation, and sales performance. The effects of eWOM are similar to those of WOM. In the hotel industry context, Verma et al. [74] analyzed 2830 surveys and found that positive reviews increase consumer willingness to book at a hotel. Ye et al. [75] collected and analyzed 5777 reviews of 248 hotels in three cities during a one-year period and found a significantly positive relationship between online consumer ratings and hotel room sales. The third hypothesis is based on this reasoning. The current research model is shown in Figure 2.

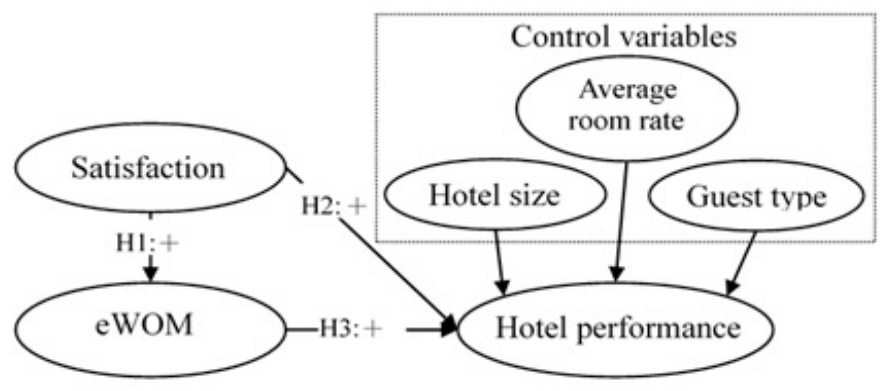

Figure 2. Research model.

Hypothesis 3. eWOM relates positively to hotel performance.

\section{Methods}

\subsection{Data Collection}

This study referred to related studies, such as [76,77], to collect and preprocess empirical data for analysis. Two datasets were employed in this empirical study. The first dataset was the Monthly Report on International and Standard Tourist Hotel Operations (MRISTHO), published by the Taiwan Tourism Bureau from December 2017 to June 2018. This official report publishes monthly operational information, such as average room rates, room revenues, food and beverage revenues, numbers of employees, and guest types (free independent traveler [FIT] or group traveler) by hotel. This report is the most complete publicly available dataset of hotels in Taiwan. A review of the MRISTHO reports from December 2017 to June 2018 found a total of 126 individual hotels that regularly reported their information.

The second dataset comprised user responses sourced from Agoda.com, Expedia.com, and Trip.com. These three platforms are well-known OTA websites that provide online booking services. The data collected from the three OTAs expands data diversity and increases the generalizability of the results [78]. All three OTAs work to maintain the quality of reviews that are posted to their site in terms of response accuracy and comment trustworthiness by only allowing users who have paid and stayed at a hotel to give 
feedback on that hotel. Consumer reviews include ratings, recommendations to stay or avoid, and detailed textual reviews. Of the 126 hotels in the dataset, all of which were in Taiwan, consistent satisfaction and recommendation information across the three OTAs was available for 88 hotels during the analytic period. These constituted the final sample.

Based on the June 2018 issue of MRISTHO, 61 of the 88 hotels in the sample were international hotels and 27 were standard hotels. The distinction between an international hotel and a standard hotel in Taiwan depends on building construction (e.g., floor space) and facilities (e.g., number of elevators). For example, based on the regulations, The Standard of International Tourist Hotel, floor space per single room must be larger than $13 \mathrm{~m}^{2}$ for international hotels in urban areas and $10 \mathrm{~m}^{2}$ for standard hotels. The hotels in the sample had an average of 268 employees. Slightly over half $(51.76 \%)$ of guests were non-Taiwanese and $48.24 \%$ were Taiwanese. Two-thirds (67.69\%) were FIT travelers and $32.31 \%$ were group travelers. Additionally, these hotels reported an average occupancy rate of $64.57 \%$ and an average room rate of US $\$ 122.35$ (The exchange rate on 14 January 2019 was 1 USD = 31.33 NTD). Room revenue accounted for the largest share of total revenue $(48.41 \%)$, followed by food and beverage services revenue $(41.59 \%)$.

\subsection{Measurement}

Analysis was conducted at the hotel level. Each consumer review of a hotel included two ratings, satisfaction and $e W O M$, respectively, which were collected monthly from the three OTAs. Satisfaction was measured using the guest rating, which reflected the reviewer's overall evaluation of her/his experience staying at a given hotel (see Figures 3-5). Guests rated their experience through responses to statements about cleanliness, room comfort and quality, service, facilities, location, and value for money (Agoda.com, 10-point scale); room cleanliness, room comfort, service and staff, and hotel condition (Expedia.com, five-point scale); cleanliness, service, facilities, and location (Trip.com, five-point scale). The average of these rankings represented the reviewer's rating. For the eWOM measure, the percentage of guests who recommend a given hotel (i.e., recommendation valence) was used. This approach follows Cantallops and Salvi's [34] suggestion that general category ratings may be more influential than detailed information (i.e., textual review) in evaluating consumer purchase decisions. Data for both ratings were retrieved at the end of each month from December 2017 to June 2018. For data homogeneity, the three sets of ratings from the three OTAs were then standardized and averaged into one satisfaction and eWOM score for each hotel [35]. The formulas are as follows:

$$
\text { standardized score }=\frac{\text { original review score }-\mu}{\sigma}
$$

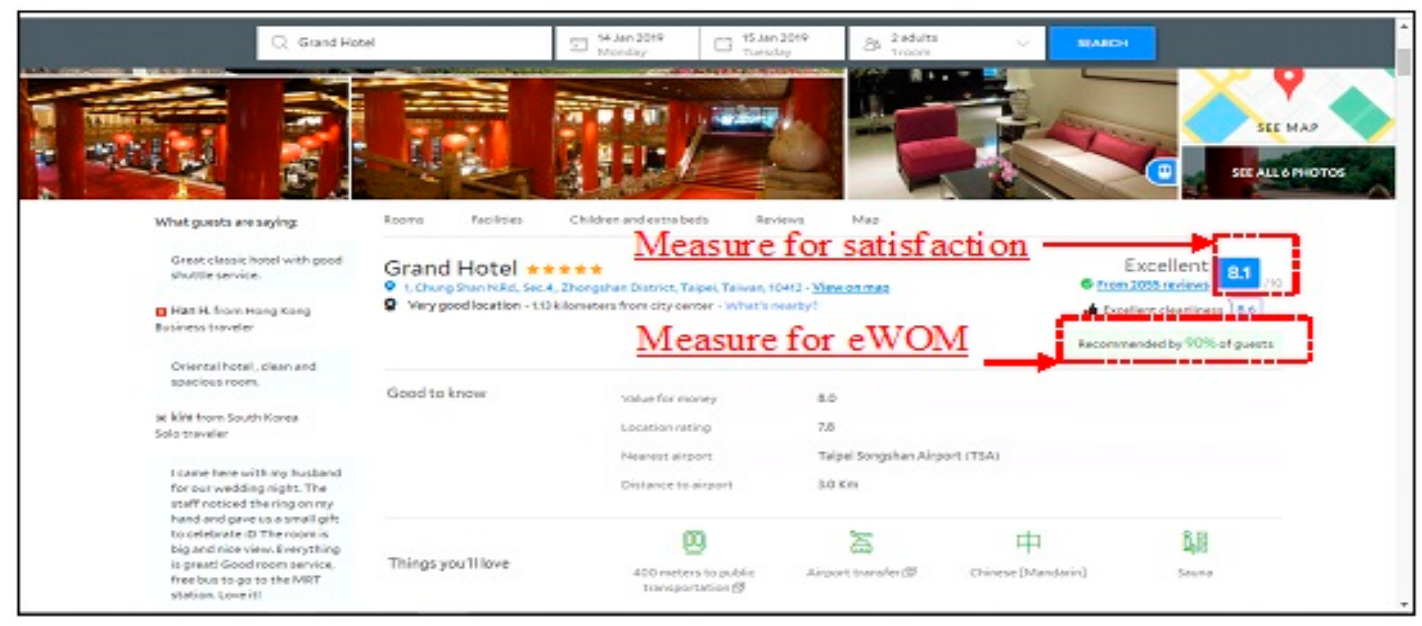

Figure 3. Measures of satisfaction and $e W O M$ on Agoda.com. 


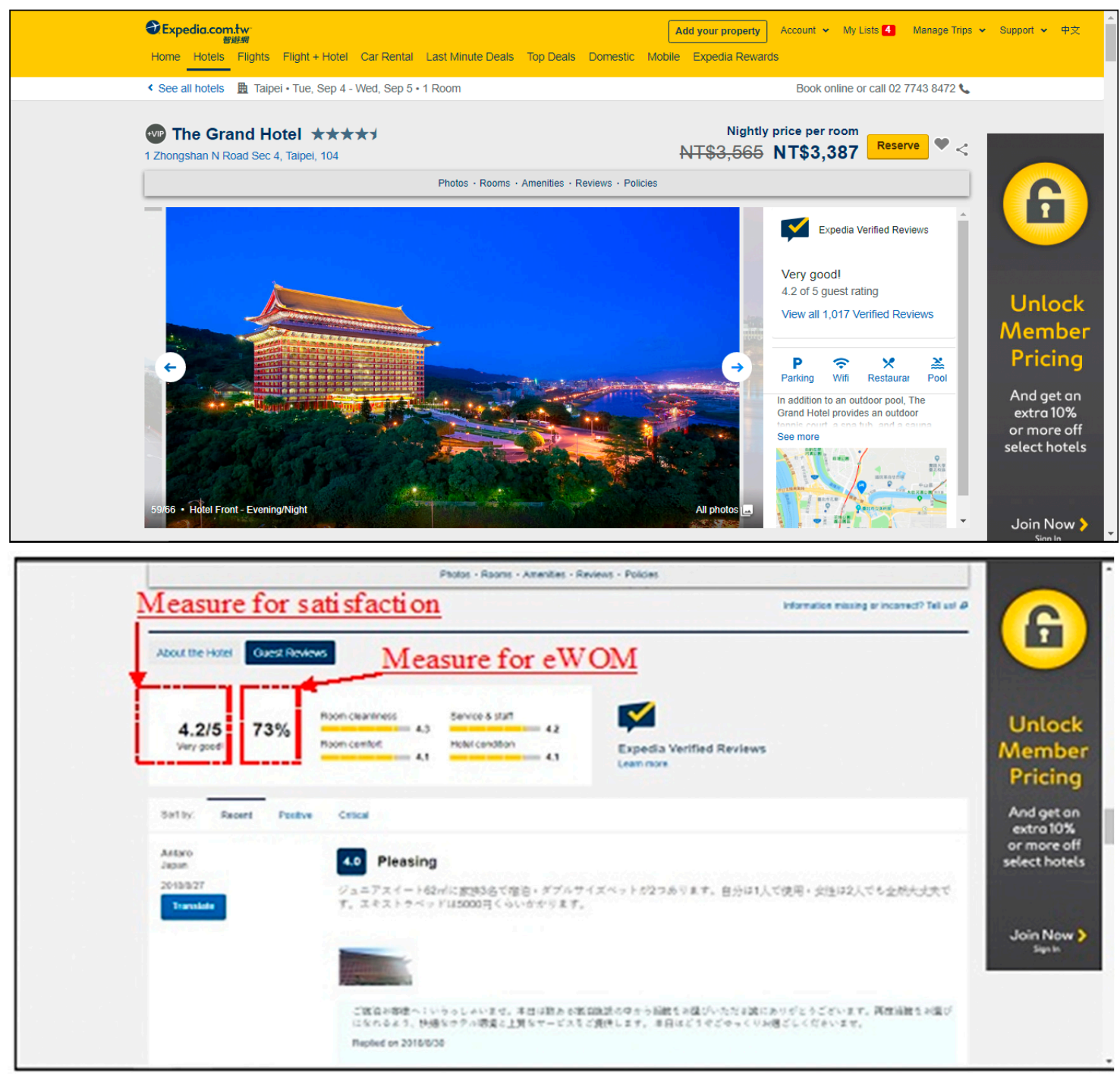

Figure 4. Measures of satisfaction and $e W O M$ on Expedia.com. 

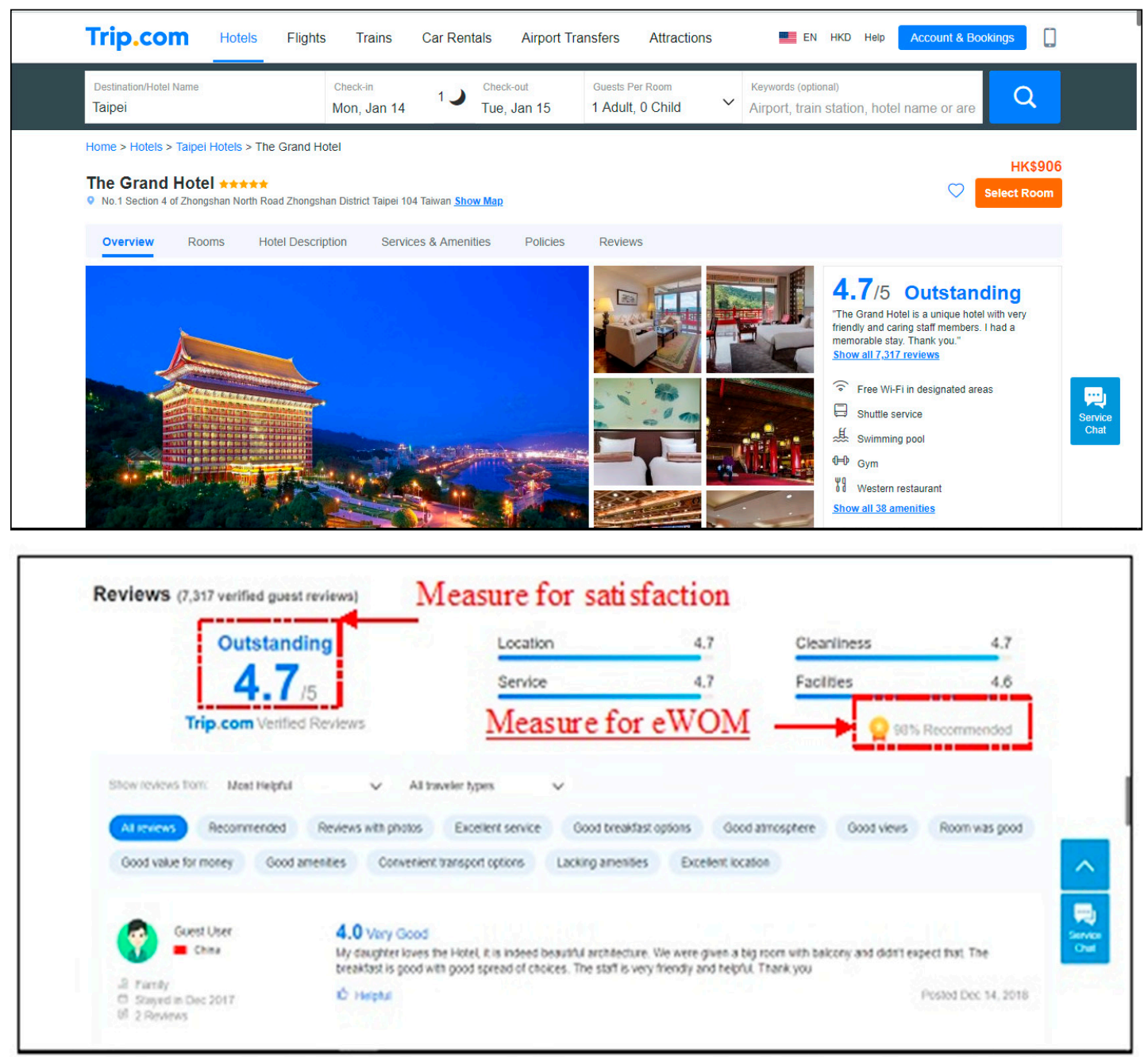

Figure 5. Measures of satisfaction and $e W O M$ on Trip.com.

$\mu$ : average, $\sigma:$ standard deviation

$$
\text { satisfaction } / \text { eWOM score }=\frac{\sum_{\text {three OTAs }} \text { standarized score }}{3}
$$

Finally, considering that satisfaction and eWOM are both accommodations-based evaluations, this study used room revenue, as reported in MRISTHO, as the proxy of hotel performance, which may be a better measure than total revenue, which includes both room and non-room revenues.

In order to separate the relationship between the two consumer ratings and hotel performance from other potential influences, the model controlled for three variables: hotel size, average room rate, and guest type. Hotel size was assessed using the number of rooms at the hotel. The average room rate adopted the mean room rate of the hotel $[29,79]$. Sin et al. [80] suggested that factors influencing accommodation decision-making may differ among different guest types (e.g., business visitors, tourists). In the present model, FITs and group travelers were chosen as the two guest types. The key difference between FIT and group travelers is that FITs are able to make accommodation decisions independently, which may be based on the reviews of previous hotel guests. Guest type was calculated as the ratio of FITs to total guest number. 


\subsection{Statistical Technique and Model Specification}

The hypotheses, including direct effects and indirect effects, were specified as suggested by Hayes [81] using a simple mediation model, Model 4, and tested using SPSS 20 and Hayes' PROCESS Macro. In order to test for the presence of concurrent and lagged effects between the independent and dependent variables, the two independent variables (satisfaction and $e W O M$ ) were specified simultaneously at times $t$, one-month lagged ( $t-1)$, 3-month lagged ( $t-3)$, and 6-month lagged ( $t-6)$ in the four models, while the dependent variable and the three control variables were fixed at time $t[21,41,65]$. The test of variance inflation factor (VIF) was also utilized to examine the severity of multicollinearity among independent variables, which may be detrimental to parameter estimation [82]. All of the VIF values of the three control variables and two independent variables at the various time points were less than 2, indicating that the paired correlations of variables were not high enough to significantly affect model estimation.

\section{Results}

This section describes the data analysis results. Section 5.1 shows the testing results of the three hypotheses. These three hypotheses correspond to the research model of Figure 2. Furthermore, due to the "satisfaction $\rightarrow e W O M \rightarrow$ performance" relationship, the mediation effect was tested and the result is presented in Section 5.2.

\subsection{Main Effects}

Hypothesis 1 examined the relationships between satisfaction and eWOM. Satisfaction was related significantly and positively to $e W O M$. Table 1 shows that the coefficients of the four models were 0.64 (Model 1a), 0.63 (Model 2a), 0.69 (Model 3a), and 0.58 (Model 4a), respectively. Thus, Hypothesis 1 is supported.

Table 1. Results of direct and indirect effect analyses: concurrent and lagged effects (cont.)

\begin{tabular}{|c|c|c|c|c|}
\hline & \multicolumn{2}{|c|}{$\begin{array}{c}\text { Model 1: } \\
\text { Concurrent Effects }\end{array}$} & \multicolumn{2}{|c|}{$\begin{array}{c}\text { Model 2: } \\
\text { One-Month Lagged Effects }\end{array}$} \\
\hline & Model 1a & Model 1b & Model 2a & Model 2b \\
\hline $\begin{array}{l}\text { Dep. Var. } \\
\text { Cont. and Ind. } \\
\text { Var. }\end{array}$ & $e W O M_{t}$ & $\begin{array}{c}\text { Hotel } \\
\text { performance }_{t}\end{array}$ & $e W O M_{\mathrm{t}-1}$ & $\begin{array}{c}\text { Hotel } \\
\text { performance }\end{array}$ \\
\hline Size $_{t}$ & & $0.73^{* * *, 1}$ & & $0.73^{* * *}$ \\
\hline Rate $_{\mathrm{t}}$ & & $0.48^{* * *}$ & & $0.49^{* * *}$ \\
\hline Guest type $_{t}$ & & 0.04 & & 0.05 \\
\hline Satisfaction $_{\mathrm{t}}$ & $0.64^{* * *}$ & -0.02 & & \\
\hline$e W O M_{t}$ & & 0.01 & & \\
\hline Satisfaction $_{\mathrm{t}-1}$ & & & $0.63^{* * *}$ & -0.03 \\
\hline$e W O M_{\mathrm{t}-1}$ & & & & -0.01 \\
\hline$R^{2}$ & 0.41 & 0.76 & 0.40 & 0.76 \\
\hline Point estimate of & & 0.00 & & -0.00 \\
\hline indirect effects & & {$[-0.10 ; 0.09]^{2}$} & & {$[-0.10 ; 0.07]$} \\
\hline
\end{tabular}

Note: ${ }^{1}$ The direct effects are standardized coefficients; ${ }^{* * *} p<0.001 ;{ }^{2}$ The indirect effects are standardized coefficients, and the numbers in the brackets are BootLLCI and BootUCLI (lower and upper levels for the confidence interval), which were calculated from 5000 bootstrap samples. Sig. denotes a significant indirect effect at 0.05 .

Hypotheses 2 and 3 predicted the satisfaction-hotel performance and eWOM-hotel performance relationships, respectively. Models $1 \mathrm{~b}$ to $4 \mathrm{~b}$ in Table 1 show the empirical results of the Hayes' PROCESS Macro, in which the three control variables were considered as well. Hotel size and average room rate significantly contributed to hotel performance, while guest type had no significant effect on hotel performance. After controlling for the three variables, satisfaction and $e W O M$ had no relationship to hotel performance across the 
concurrent effects model and three lagged effects models. Thus, Hypotheses 2 and 3 are not supported.

\subsection{Mediation Effects}

Based on the results for the main effects, satisfaction predicted eWOM but not hotel performance. Different from Baron and Kenny's argument [83], it is possible to examine whether $e W O M$ may mediate the relationship between satisfaction and hotel performance. Zhao et al. [84] advanced Baron and Kenny's procedures [83] and suggested that a mediation effect is sustained if the product of all of the coefficients in the mediation relationships (i.e., indirect effects) are significant. Therefore, the mediation analysis used the PROCESS Macro and evaluated the point estimate of indirect effects in Table 1. For all four models, each point estimate was close to 0 , and the $95 \%$ confidence interval derived from 5000 bootstrap samples included 0 [85] (Preacher and Hayes, 2004). Thus, all of the point estimates were found to be insignificant, and no mediation effects were found.

\section{Discussion}

Although consumer response has long been a topic of interest for academics and practitioners, evidence on whether and how consumer responses relate to business revenue and profitability has been inconclusive. This study aims to investigate the relationships between consumer responses and firm performance in terms of the SPC framework in the online hotel booking context. Prior studies on the SPC framework mostly measure consumer loyalty with repurchase behavior. However, word-of-mouth (WOM) is also a type of loyalty [51]. Loyal consumers often willingly share their firsthand experiences with others and encourage them to make purchases from those firms [55]. Therefore, this study modifies the SPC framework to online satisfaction-eWOM-performance linkage and explores whether the two online consumer responses (satisfaction and $e W O M$ ), which are characterized as long-lasting and fast-disseminating, have immediate and/or delayed effects on hotel revenues, which is less discussed in studies.

The analyses in this study, one concurrent model and three lagged models, using Hayes's PROCESS Macro [81] did not establish a satisfaction-eWOM-hotel performance linkage. Moreover, although consumer satisfaction was found to be highly related to $e W O M$ across all of the analytic models, direct satisfaction-revenue and $e W O M$-revenue relationships were not found. A reason for these insignificant findings might be that high consumer responses reflected the resource inputs of the hotels. Anderson et al. pointed out that although customized services may garner more consumer satisfaction, the benefit created might not justify the costs of customization [9]. High operational costs may lessen the benefits of increased hotel revenues. The findings of the current study echo Terpstra and Verbeeten's [67] conclusion that satisfaction is both a value driver and a cost driver. Both effects are intertwined, so the direct impacts of satisfaction on financial performance are difficult to predict accurately. Lin and Heng [86] proposed the "WOM valence paradox," which argues that positive $e W O M$ valence for a firm drives sales growth as well as heightens consumer expectations. As business growth increases, the company is unable to cope, leading to unmet consumer expectations and negative WOM and decreased sales. In this study, the maximum variance of online consumer satisfaction and eWOM valence for each hotel from the three OTAs was 0.41 , and no significant decay was found. Therefore, as previously suggested by Terpstra and Verbeeten [67], eWOM may play a hybrid role with satisfaction, and $e W O M$ might not significantly contribute to hotel performance.

Another explanation for the insignificance of the satisfaction/eWOM-performance relationship may be that potential consumers use these two metrics to screen out alternatives and then use other information for a more comprehensive evaluation before deciding where to stay. Prior information-processing studies have revealed that consumers adopt a two-stage evaluation process in order to have efficient choice-making [87]. Bettman and Park [88] suggested that consumers may employ an attribute-based strategy, which is less effortful, to minimize the consideration set in the early stages of the decision process and 
then use a brand-based strategy for a holistic product evaluation in later stages. In the context of online hotel booking, consumers may search an OTA website and identify a number of candidate hotels using the two metrics, satisfaction and $e W O M$, to filter the selection set. Then they use other information, such as textual reviews or photos, for further evaluations, providing them with an efficient decision-making process. Though Cantallops and Salvi [34] argued that numerical review information may be easier than textual review information for hotel evaluation, recent studies have found that textual reviews provide richer information for product sales than numerical ratings and are better predictors [89]. In this regard, online satisfaction and $e W O M$ are important quality signals and aid in reducing information overload, but they may not play decisive roles in the decision to buy.

\section{Conclusions}

This study empirically investigates the effects of online consumer reviews on hotel accommodation performance in an e-commerce context. Online consumer reviews include two important forms: online consumer satisfaction and $e W O M$. The results indicate that satisfaction has a positive effect on $e W O M$ and the two forms of online consumer reviews do not directly affect hotel accommodation performance. The results have several important theoretical and practical implications for online consumer relationship management in the hospitality and tourism industry.

\subsection{Theoretical Implications}

Building on the SPC framework, which focuses on repurchase intention and behavior, the current study examined whether $\mathrm{eWOM}$, a measure of consumer loyalty, and online satisfaction have positive impacts on hotel revenues. Overall, the analysis generated informative results using timely consumer response data and hotel performance data (room revenue). Furthermore, the validity of this study was enhanced by controlling for the effects of hotel size, average room rate, and guest type. Several theoretical implications of this study are outlined in the following paragraphs.

First, previous studies have incorporated market structure into the SPC framework. Unlike the Steven et al. [90] proposal that the weak relationship between consumer satisfaction and firm performance is attributed to a less-competitive market structure or high firm dominance, the results of the current study suggest this link is unimportant in industries (such as the hotel industry) that regularly face intensive competition. Firms in highly competitive environments must invest relatively large amounts of resources in order to satisfy consumers, even though the resultant rise in revenues may not fully cover the investment.

Second, Bernhardt et al. [21] examined the relationship between satisfaction and restaurant performance using longitudinal data from a single year and found that satisfaction mainly influences performance over the long run. Over the short run, satisfaction might not be influential because other factors (e.g., sales promotions) have immediate effects on restaurant performance. The present study examined the effects of online consumer reviews on hotel room revenues in terms of the concurrent model and three lagged models under the hypothesis that online consumer responses are long-lasting and disseminate quickly. However, the results indicate that neither online satisfaction nor eWOM related significantly to hotel performance in terms of both the concurrent and lagged effects.

Third, results from multiple studies on WWOM are similar to this study. Duan et al. [91] tested the relationships between online eWOM and sales in the movie industry using 71 balanced panel datasets. By defining eWOM metrics as review valence and review volume, they found that movie sales are significantly influenced by volume but not by valence. They reported that $e W O M$ is influential in terms of awareness effects, as measured by volume, but not in terms of persuasive effects, as measured by valence. In addition, a meta-analysis by Rosario et al. [92] found the effects of eWOM volume to be stronger than those of $e W O M$ valence. Conversely, a meta-analysis by Yang et al. [93] reported that the elasticity of valence-based $e W O M$ is twice as large as that of volume-based $e W O M$, indi- 
cating that the effects of valence-based $e W O M$ on hotel performance are more significant. Duverger [94] found evidence that an inverted U-shaped relationship exists in the eWOMhotel performance linkage. Considering these conflicting results, the relationship between online consumer response and hotel performance requires further academic inquiry using a wide range of datasets and analytic methods.

Fourth, two control variables, hotel size and room rate, significantly contributed to hotel performance rather than the two focal predictors, satisfaction and eWOM. Kim et al. [29] showed that the number of rooms is significantly positively related to revenue per available room and argued that hotel size may be influential for performance in terms of economies of scale. Gu [95] explained that economies of scale may manifest as cost-savings and efficiency, and be realized in procurement, management, personnel, marketing, and finance. Additionally, Chattopadhyay and Mitra [96] found that the average daily rate (i.e., room rate) is positively associated with revenue per available room (i.e., performance). One possible influence on room rate is brand positioning [97]. More academic research is needed to understand the theoretical underpinnings of the relationships between hotel size, room rate, and hotel performance.

\subsection{Managerial Implications}

The findings suggest that hoteliers should adopt two important strategic actions in order to improve business performance. First, the two types of online consumer ratings failed to predict hotel performance; therefore, hotel managers need to reconsider the roles of online satisfaction and $e W O M$ scores. Although online satisfaction and $e W O M$ ratings are long-lasting and disseminate rapidly, they may not necessarily elevate room revenues. However, considering relevant studies have mixed results on this issue, and consumers may use the two metrics as preliminary criteria to filter their choice set, managers should still endeavor to improve consumer satisfaction and encourage consumers to leave positive reviews. As indicated in the results of this study, consumer satisfaction is a key driver of positive $e W O M$.

The altruistic eWOM behavior of consumers could spread knowledge to other potential consumers, which may reduce consumer perceptions of risk. Despite the finding that the two metrics do not directly influence hotel revenue, they may still play a significant role in consumer evaluations.

A second strategic action for hoteliers is to tailor satisfaction enhancement programs that increase consumer satisfaction and $e W O M$ behaviors [21]. However, these programs must carefully balance the resources invested with the expected benefits of higher consumer satisfaction in order to avoid an overall negative impact on hotel profitability. Therefore, prioritizing the relative importance of hotel attributes is imperative. Phillips et al. [69] suggested that room quality contributes to $66.9 \%$ of the total variance of positive WOM for hotels, followed by Internet provision $(16.2 \%)$ and building $(10.7 \%)$. Thus, managers should consider focusing their resources and attention on room quality in order to elicit the strongest boost to consumer evaluations.

\subsection{Limitations and Future Directions for Study}

This study is affected by three main limitations. First, the data comprised two metrics that were collected from three well-known online booking websites. Future studies should collect consumer responses from additional sources and test whether these validate the present findings [69]. Second, the hotel performance data (room revenue) used in this study did not distinguish between return and first-time visitors. If possible, future studies should examine the respective influence of $e W O M$ on repeat consumers and first-time consumers. Finally, future studies should include quality attributes in the model and examine all of the relationships among the elements in the SPC framework using simultaneous-equation models.

Author Contributions: Conceptualization, Y.-M.W., Y.-S.W., and S.-j.L.; methodology, T.H.T.; investigation, S.-H.C. All authors have read and agreed to the published version of the manuscript. 
Funding: This research received no external funding.

Informed Consent Statement: Not applicable.

Data Availability Statement: The data will be available from the corresponding author upon request.

Acknowledgments: The authors would like to thank Ching-Hsuan Yeh for his kind help on collecting the sample data.

Conflicts of Interest: The authors declare no conflict of interest.

\section{References}

1. Pan, Y.; Sheng, S.; Xie, F.T. Antecedents of customer loyalty: An empirical synthesis and reexamination. J. Retail. Consum. Serv. 2012, 19, 150-158. [CrossRef]

2. Chou, S.; Chen, C.W.; Lin, J.Y. Female online shoppers: Examining the mediating roles of e-satisfaction and e-trust on e-loyalty development. Internet Res. 2015, 25, 542-561. [CrossRef]

3. Cooil, B.; Keiningham, T.L.; Aksoy, L.; Hsu, M. A longitudinal analysis of customer satisfaction and share of wallet: Investigating the moderating effect of customer characteristics. J. Mark. 2007, 71, 67-83. [CrossRef]

4. Dick, A.S.; Basu, K. Customer loyalty: Toward an integrated conceptual framework. J. Acad. Mark. Sci. 1994, 22, 99-113. [CrossRef]

5. Oliver, R.L. A cognitive model of the antecedents and consequences of satisfaction decisions. J. Mark. Res. 1980, 17, 460-469. [CrossRef]

6. Oliver, R.L. Whence consumer loyalty? J. Mark. 1999, 63, 33-44. [CrossRef]

7. Yu, X.; Roy, S.K.; Quazi, A.; Nguyen, B.; Han, Y. Internet entrepreneurship and "the sharing of information in an Internet-of-Things context: The role of interactivity, stickiness, e-satisfaction and word-of-mouth in online SMEs' websites". Internet Res. 2017, 27, 74-96. [CrossRef]

8. Zhang, M.; Luo, N. Understanding relationship benefits from harmonious brand community on social media. Internet Res. 2016, 26, 809-826. [CrossRef]

9. Anderson, E.W.; Fornell, C.; Rust, R.T. Customer satisfaction, productivity, and profitability: Differences between goods and services. Mark. Sci. 1997, 16, 129-145. [CrossRef]

10. Kamakura, W.A.; Mittal, V.; de Rosa, F.; Mazzon, J.A. Assessing the service-profit chain. Mark. Sci. 2002, 21, 294-317. [CrossRef]

11. Mouakket, S.; Al-hawari, M.A. Examining the antecedents of e-loyalty intention in an online reservation environment. J. High. Technol. Manag. Res. 2012, 23, 46-57. [CrossRef]

12. Chand, M. The impact of HRM practices on service quality, customer satisfaction and performance in the Indian hotel industry. Int. J. Hum. Resour. Manag. 2010, 21, 551-566. [CrossRef]

13. Chen, S.C. Customer value and customer loyalty: Is competition a missing link? J. Retail. Consum. Serv. 2015, 22, 107-116. [CrossRef]

14. Kim, K.H.; Park, D.B. Relationships among perceived value, satisfaction, and loyalty: Community-based ecotourism in Korea. J. Travel Tour. Mark. 2017, 34, 171-191. [CrossRef]

15. Shaikh, A.A.; Karjaluoto, H.; Häkkinen, J. Understanding moderating effects in increasing share-of-wallet and word-of-mouth: A case study of Lidl grocery retailer. J. Retail. Consum. Serv. 2018, 44, 45-53. [CrossRef]

16. Chi, C.G.; Gursoy, G. Employee satisfaction, customer satisfaction, and financial performance: An empirical examination. Int. J. Hosp. Manag. 2009, 28, 245-253. [CrossRef]

17. Gelade, G.A.; Young, S. Test of a service profit chain model in the retail banking sector. J. Occup. Organ. Psychol. 2005, 78, 1-22. [CrossRef]

18. Kim, G.-J. Applying Service Profit Chain model to the Korean restaurant industry. Int. J. Hosp. Manag. 2014, 36, 1-13. [CrossRef]

19. Heskett, J.L.; Jones, T.O.; Loveman, G.W.; Sasser, W.E., Jr.; Schlesinger, L.A. Putting the service-profit chain to work. Harv. Bus. Rev. 1994, 72, 164-170.

20. Kim, H.; Kim, W.G. The relationship between brand equity and firms' performance in luxury hotels and chain restaurants. Tour. Manag. 2005, 26, 549-560. [CrossRef]

21. Bernhardt, K.L.; Donthu, N.; Kennett, P.A. A longitudinal analysis of satisfaction and profitability. J. Bus. Res. 2000, 47, 161-171. [CrossRef]

22. Gupta, S.; Zeithaml, V. Customer metrics and their impact on financial performance. Mark. Sci. 2006, 25, 718-739. [CrossRef]

23. Schneider, B. Service quality and profits: Can you have your cake and eat it, too? Hum. Resour. Plan. 1991, 14, 151-157.

24. Wiley, J.W. Customer satisfaction: A supportive work environment and its financial cost. Hum. Resour. Plan. 1991, 14, 117-127.

25. Cohen, J.F.; Olsen, K. The impacts of complementary information technology resources on the service-profit chain and competitive performance of South African hospitality firms. Int. J. Hosp. Manag. 2013, 34, 245-254. [CrossRef]

26. Deng, W.J.; Yeh, M.L.; Sung, M.L. A customer satisfaction index model for international tourist hotels: Integrating consumption emotions into the American Customer Satisfaction Index. Int. J. Hosp. Manag. 2013, 35, 133-140. [CrossRef]

27. Ekinci, Y.; Dawes, P.L.; Massey, G.R. An extended model of the antecedents and consequences of consumer satisfaction for hospitality services. Eur. J. Mark. 2008, 42, 35-68. [CrossRef] 
28. Nam, J.; Ekinci, Y.; Whyatt, G. Brand equity, brand loyalty and consumer satisfaction. Ann. Tour. Res. 2011, 38, 1009-1030. [CrossRef]

29. Kim, W.G.; Cho, M.; Brymer, R.A. Determinants affecting comprehensive property-level hotel performance: The moderating role of hotel type. Int. J. Hosp. Manag. 2013, 34, 404-412. [CrossRef]

30. Lee, C.G.; How, S.M. Long-run causality between customer satisfaction and financial performance: The case of Marriott. Curr. Issues Tour. 2018, 1-6. [CrossRef]

31. Koo, D.-M. Impact of tie strength and experience on the effectiveness of online service recommendations. Electron. Commer. Res. Appl. 2016, 15, 38-51. [CrossRef]

32. Loureiro, S.M.C.; Kastenholz, E. Corporate reputation, satisfaction, delight, and loyalty towards rural lodging units in Portugal. Int. J. Hosp. Manag. 2011, 30, 575-583. [CrossRef]

33. Hu, Y.H.; Chen, K. Predicting hotel review helpfulness: The impact of review visibility, and interaction between hotel stars and review ratings. Int. J. Inf. Manag. 2016, 36, 929-944. [CrossRef]

34. Cantallops, A.S.; Salvi, F. New consumer behavior: A review of research on eWOM and hotels. Int. J. Hosp. Manag. 2014, 36, 41-51. [CrossRef]

35. Viglia, G.; Minazzi, R.; Buhalis, D. The influence of e-word-of-mouth on hotel occupancy rate. Int. J. Contemp. Hosp. Manag. 2016, 28, 2035-2051. [CrossRef]

36. Verma, R. Customer choice modeling in hospitality services: A review of past research and discussion of some new applications. Cornell Hosp. Q. 2010, 51, 470-478. [CrossRef]

37. Pan, B.; Zhang, L.; Law, R. The complex matter of online hotel choice. Cornell Hosp. Q. 2013, 54, 74-83. [CrossRef]

38. Chiou, J.-S.; Droge, C. Service quality, trust, specific asset investment, and expertise: Direct and indirect effects in a satisfactionloyalty framework. J. Acad. Mark. Sci. 2006, 34, 613-627. [CrossRef]

39. Liao, Y.-W.; Wang, Y.-S.; Yeh, C.-H. Exploring the relationship between intentional and behavioral loyalty in the context of e-tailing. Internet Res. 2014, 24, 668-686. [CrossRef]

40. De Nicola, F.; Giné, X. How accurate are recall data? Evidence from coastal India. J. Dev. Econ. 2014, 106, 52-65. [CrossRef]

41. Evanschitzky, H.; Wangenheim, F.v.; Wünderlich, N.V. Perils of managing the service profit chain: The role of time lags and feedback loops. J. Retail. 2012, 88, 356-366. [CrossRef]

42. Yeung, M.C.H.; Ging, L.C.; Ennew, C.T. Customer satisfaction and profitability: A reappraisal of the nature of the relationship. J. Target. Meas. Anal. Mark. 2002, 11, 24-33. [CrossRef]

43. Hernandez-Ortega, B. What about “U”? The Influence of Positive Online Consumer Reviews on the Individual's Perception of Consumption Benefits. Online Inf. Rev. 2020, 44, 863-885. [CrossRef]

44. BrightLocal, Local Consumer Review Survey. 2019. Available online: https://www.brightlocal.com/research/local-consumerreview-survey-2019/ (accessed on 5 February 2020).

45. Lee, J.; Park, D.H.; Han, I. The different effects of online consumer reviews on consumers' purchase intentions depending on trust in online shopping malls. Internet Res. 2011, 21, 187-206. [CrossRef]

46. Anastasiei, B.; Dospinescu, N. Electronic word-of-mouth for online retailers: Predictors of volume and valence. Sustainability 2019, 11, 814. [CrossRef]

47. Homburg, C.; Koschate, N.; Hoyer, W.D. The role of cognition and affect in the formation of customer satisfaction: A dynamic perspective. J. Mark. 2006, 70, 21-31. [CrossRef]

48. Han, H.; Kim, Y.; Kim, E.-K. Cognitive, affective, conative, and action loyalty: Testing the impact of inertia. Int. J. Hosp. Manag. 2011, 30, 1008-1019. [CrossRef]

49. Hoare, R.J.; Butcher, K. Do Chinese cultural values affect customer satisfaction/loyalty? Int. J. Contemp. Hosp. Manag. 2008, 20, 156-171. [CrossRef]

50. Ryu, K.; Lee, H.-R.; Kim, W.G. The influence of the quality of the physical environment, food, and service on restaurant image, customer perceived value, customer satisfaction, and behavioral intentions. Int. J. Contemp. Hosp. Manag. 2012, 24, $200-223$. [CrossRef]

51. Chang, K.-C. How reputation creates loyalty in the restaurant sector. Int. J. Contemp. Hosp. Manag. 2013, 25, 536-557. [CrossRef]

52. Kivela, J.; Inbakaran, R.; Reece, J. Consumer research in the restaurant environment, Part 1: A conceptual model of dining satisfaction and return patronage. Int. J. Contemp. Hosp. Manag. 1999, 11, 205-222. [CrossRef]

53. Meyer-Waarden, L. The effects of loyalty programs on customer lifetime duration and share of wallet. J. Retail. 2007, 83, 223-236. [CrossRef]

54. Pan, Y.; Zinkhan, G.M. Determinants of retail patronage: A meta-analytical perspective. J. Retail. 2006, 82, 229-243. [CrossRef]

55. Bansal, H.S.; Voyer, P.A. Word-of-Mouth processes within a services purchase decision context. J. Serv. Res. 2000, 3, 166-177. [CrossRef]

56. Fullerton, G. When does commitment lead to loyalty? J. Serv. Res. 2003, 5, 333-344. [CrossRef]

57. Hennig-Thurau, T.; Gwinner, K.P.; Walsh, G.; Gremler, D.D. Electronic word-of-mouth via consumer-opinion platforms: What motivates consumers to articulate themselves on the Internet? J. Interact. Mark. 2004, 18, 38-52. [CrossRef]

58. Laczniak, R.N.; DeCarlo, T.E.; Ramaswami, S.N. Consumers' responses to negative word-of-mouth communication: An attribution theory perspective. J. Consum. Psychol. 2001, 11, 57-73. [CrossRef] 
59. Hennig-Thurau, T.; Walsh, G. Electronic word of mouth: Motives for and consequences of reading customer articulations on the Internet. Int. J. Electron. Commer. 2003, 8, 51-74. [CrossRef]

60. King, R.A.; Racherla, P.; Bush, V.D. What we know and don't know about online word-of-mouth: A review and synthesis of the literature. J. Interact. Mark. 2014, 28, 167-183. [CrossRef]

61. Yen, C.L.A.; Tang, C.H.H. The effects of hotel attribute performance on electronic word-of-mouth (eWOM) behaviors. Int. J. Hosp Manag. 2019, 76, 9-18. [CrossRef]

62. Jalilvand, M.R.; Salimipour, S.; Elyasi, M.; Mohammadi, M. Factors influencing word of mouth behaviour in the restaurant industry. Mark. Intell. Plan. 2017, 35, 81-110. [CrossRef]

63. Wirtz, J.; Chew, P. The effects of incentives, deal proneness, satisfaction, and tie strength on word-of-mouth behavior. Int. J. Serv. Ind. Manag. 2002, 13, 141-162. [CrossRef]

64. Crotts, J.C.; Mason, P.R.; Davis, B. Measuring guest satisfaction and competitive position in the hospitality and tourism industry: An application of stance-shift analysis to travel blog narratives. J. Travel Res. 2009, 48, 139-151. [CrossRef]

65. Guo, C.; Kumar, A.; Jiraporn, P. Customer satisfaction and profitability: Is there a lagged effect? J. Strateg. Mark. 2004, 12, 129-144. [CrossRef]

66. Yeung, M.C.H.; Ennew, C.T. Measuring the impact of customer satisfaction on profitability: A sectoral analysis. J. Target. Meas. Anal. Mark. 2001, 10, 106-116. [CrossRef]

67. Terpstra, M.; Verbeeten, F.H.M. Customer satisfaction: Cost driver or value driver? Empirical evidence from the financial services industry. Eur. Manag. J. 2014, 32, 499-508. [CrossRef]

68. Sun, K.-A.; Kim, D.-Y. Does customer satisfaction increase firm performance? An application of American Customer Satisfaction Index (ACSI). Int. J. Hosp. Manag. 2013, 35, 68-77. [CrossRef]

69. Phillips, P.; Barnes, S.; Zigan, K.; Schegg, R. Understanding the impact of online reviews on hotel performance: An empirical analysis. J. Travel Res. 2017, 56, 1-15. [CrossRef]

70. Aaker, D.A. Managing Brand Equity; Free Press: San Francisco, CA, USA, 1991.

71. Helgesen, $\varnothing$. Are loyal customers profitable? Customer satisfaction, customer (action) loyalty and customer profitability at the individual level. J. Mark. Manag. 2006, 22, 245-266. [CrossRef]

72. Xie, K.L.; Zhang, Z.; Zhang, Z.; Singh, A.; Lee, S.K. Effects of managerial response on consumer eWOM and hotel performance: Evidence from TripAdvisor. Int. J. Contemp. Hosp. Manag. 2016, 28, 2013-2034. [CrossRef]

73. Luo, X.; Homburg, C. Neglected outcomes of customer satisfaction. J. Mark. 2007, 71, 133-149. [CrossRef]

74. Verma, R.; Stock, D.; McCarthy, L. Customer preferences for online, social media, and mobile innovations in the hospitality industry. Cornell Hosp. Q. 2012, 53, 183-186. [CrossRef]

75. Ye, Q.; Law, R.; Gu, B. The impact of online user reviews on hotel room sales. Int. J. Hosp. Manag. 2009, 28, 180-182. [CrossRef]

76. Khosravy, M.; Gupta, N.; Marina, N.; Sethi, I.K.; Asharif, M.R. Morphological filters: An inspiration from natural geometrical erosion and dilation. In Nature-Inspired Computing and Optimization; Springer: Cham, Switzerland, 2017; pp. 349-379.

77. Wang, R.; Wang, G. Web text categorization based on statistical merging algorithm in big data environment. Int. J. Ambient Comput. Intell. 2019, 10, 17-32. [CrossRef]

78. Floyd, K.; Freling, R.; Alhoqail, S.; Cho, H.Y.; Freling, T. How Online Product Reviews Affect Retail Sales: A Meta-analysis. J. Retail. 2014, 90, 217-232. [CrossRef]

79. Saeidi, S.P.; Sofian, S.; Saeidi, P.; Saeidi, S.P.; Saaeidi, S.A. How does corporate social responsibility contribute to firm financial performance? The mediating role of competitive advantage, reputation, and customer satisfaction. J. Bus. Res. 2015, 68, 341-350. [CrossRef]

80. Sin, L.Y.M.; Tse, A.C.B.; Heung, V.C.S.; Yim, F.H.K. An analysis of the relationship between market orientation and business performance in the hotel industry. Int. J. Hosp. Manag. 2005, 24, 555-577. [CrossRef]

81. Hayes, A.F. Introduction to Mediation, Moderation, and Conditional Process Analysis: A Regression-Based Approach 2013; The Guilford Press: New York, NY, USA, 2013.

82. Maddala, G.S.; Lahiri, K. Introduction to Econometrics; Wiley: Hoboken, NJ, USA, 2009.

83. Baron, R.M.; Kenny, D.A. The moderator-mediator variable distinction in social psychological research: Conceptual, strategic, and statistical considerations. J. Personal. Soc. Psychol. 1986, 51, 1173-1182. [CrossRef]

84. Zhao, X.; Lynch, J.G.; Chen, Q. Reconsidering Baron and Kenny: Myths and truths about mediation analysis. J. Consum. Res. 2010, 37, 197-206. [CrossRef]

85. Preacher, K.J.; Hayes, A.F. SPSS and SAS procedures for estimating indirect effects in simple mediation models. Behav. Res. Methods Instrum. Comput. 2004, 36, 717-731. [CrossRef]

86. Lin, Z.; Heng, C.-S. The paradoxes of word of mouth in electronic commerce. J. Manag. Inf. Syst. 2015, 32, 246-284. [CrossRef]

87. Gilbride, T.J.; Allenby, G.M. A choice model with conjunctive, disjunctive, and compensatory screening rules. Mark. Sci. 2004, 23, 391-406. [CrossRef]

88. Bettman, J.R.; Park, C.W. Effects of prior knowledge and experience and phase of the choice process on consumer decision processes: A protocol analysis. J. Consum. Res. 1980, 7, 234-248. [CrossRef]

89. Chen, K.; Luo, P.; Wang, H. An influence framework on product word-of-mouth (WoM) measurement. Inf. Manag. 2017, 54, 228-240. [CrossRef] 
90. Steven, A.B.; Dong, Y.; Dresner, M. Linkages between customer service, customer satisfaction and performance in the airline industry: Investigation of non-linearities and moderating effects. Transp. Res. Part E 2012, 48, 743-754. [CrossRef]

91. Duan, W.; Gu, B.; Whinston, A.B. The dynamics of online word-of-mouth and product sales: An empirical investigation of the movie industry. J. Retail. 2008, 84, 233-242. [CrossRef]

92. Rosario, A.B.; Sotgiu, F.; de Valck, K.; Bijmolt, T.H.A. The effect of electronic word of mouth on sales: A meta-analytic review of platform, product, and metric factors. J. Mark. Res. 2016, 53, 297-318. [CrossRef]

93. Yang, Y.; Park, S.; Hu, X. Electronic word of mouth and hotel performance: A meta-analysis. Tour. Manag. 2018, 67, 248-260. [CrossRef]

94. Duverger, P. Curvilinear effects of user-generated content on hotels' market share: A dynamic panel-data analysis. J. Travel Res. 2013, 52, 465-478. [CrossRef]

95. Gu, Z. Economies of scale could be key to profitability. Int. J. Hosp. Tour. Adm. 2005, 6, 73-85. [CrossRef]

96. Chattopadhyay, M.; Mitra, S.K. Determinants of revenue per available room: Influential roles of average daily rate, demand, seasonality and yearly trend. Int. J. Hosp. Manag. 2019, 77, 573-582. [CrossRef]

97. Israeli, A.A. Star rating and corporate affiliation: Their influence on room price and performance of hotels in Israel. Int. J. Inf. Manag. 2002, 21, 405-424. [CrossRef] 